\section{Researchers begin life again}

\section{Bucharest}

After 25 years of the Ceausescu dictatorship, researchers in Romania again have hopes of progress. The provisional government plans to improve the lot of basic research and the first concrete steps in that direction are now being taken.

The National Salvation Front, which took power from dictator Nicolae Ceausescu in the December revolution and set up a provisional government, has endeared itself to researchers by restoring cuts in their salaries made by the Ceausescu regime.

In industry, as well, workers had to 'loan' the government up to 40 per cent of their pay for months at a time in order to build new factories. These cuts, too, have been restored.

There is some scepticism about the promises of the Front. Its nickname among dissenters is the Nomenklatura Salvation Front, nomenklatura being the leading Communists from the old regime. And even the Deputy Minister for Environment, M. G. Negulescu, admits that with the Front issuing "ten decrees a day", it is hard to know what to believe. But perhaps because they have no choice, researchers trust the Front when it says it has the best interests of science at heart.

Dan Balteanu, the new democratically elected director of the Institute for Geography affiliated with the Education Ministry, said the Front sees supporting science "from below" in a decentralized manner as a "noble thing". Balteanu was especially encouraged when the Front almost instantly disbanded the hated National Council for Scientific Research (NCSR), which used to run Romanian science under the watchful eye of Elena Ceausescu, the dictators's wife.

Two weeks ago, the Front issued a decree including a new set of by-laws for the Romanian Academy. Most important among these, say researchers, were the articles granting autonomy to the academy and stating that its main purpose is supporting basic research.

This is a complete turnaround from the policy of the Ceausescu regime, under which the NCSR severed the academy from its 51 research institutes (including the Institute for Geography). The institutes had to turn more and more to applied research in order to function as their support was cut. According to the Front, many institutes will be restored to the academy later this year and their support will be guaranteed.

The Front set up a 'Salvation Committee' for the academy just ten days after the revolution. Led by Professor Milcu, an 85-year-old endocrinologist, the committee prepared a secret ballot among the academy's remaining members, whose average age is over 75 , to elect a president Their unanimous choice, Mihai Draganescus is an information scientist whose also a vice-prime minister in the provisional government.

The changes in the academy do not make everyone happy. A few of its previous administrators have resigned to make way for the new leadership but in the institutes themselves there is a "fantastic power struggle all over", reported one researcher at the Institute for Biology. People instrumental in the old regime are "fighting tooth and nail" to hang onto their positions, said Nicolae Botnariuc, the new head of the biology section in the academy. Not only are they concerned about losing their salary or their title; many of them are so incompetent that they "would not be able to cope with life outside of their institutes". The Ceausescu regime tried to kill intellectual talent. "They limited us in any way they could", said Serban Dragomirescu of the Institute of Geography. Personnel, training, transportation, documentation, foreign travel and even simple office equipment were subject to exasperating restrictions; the typewriters in the institute could be used only with permission from the NCSR. The latest piece of equipment was bought for the institute in 1975 .

Even Romanian-produced photographic film was made inaccessible to the geographers a few years ago because of an ostensible shortage of silver. Film and other supplies sent by foreign colleagues could not be received without going through humiliating formalities, said Dragomirescu, so it often never reached the institute.

Collaborations were effectively stopped by the regime, which forbade researchers from travelling or receiving visitors or even answering letters from abroad. Needless to say, researchers are desperate to re-establish the contacts they once had or to establish new ones.

"We could not even exploit the talent we had in the country", lamented Dragomirescu, because the regime allowed the institute to recruit new employees only from Bucharest.

The geographers learned to be grateful for small victories. They displayed with pride a copy of the Romanian National Atlas, which was published by the institute in 1979. They are not only proud of the oversize, colourful atlas - they considered it a moral victory that 10,000 copies were produced and not one has a photograph of Ceausescu in it

A few researchers were sceptical of the new academy plan because of the implicit centralized structure that it imposes on basic research. S. A. Hulea of the Institute institute was abolished in the 1970 s. He is

\section{Scholarships offered}

\author{
New Delhi
}

INDIA will provide scholarships to $\mathbf{5 0 0}$ undergraduate and postgraduate Sri Lankan students whose studies have been interrupted by the closure of educational institutions amid continuing ethnic violence. The students, including Sri Lankan Tamils, will be placed in various universities and colleges in India during the 1990-91 academic year.

Professor Cyril Ponnemperuma, scientific adviser to the Sri Lankan president, who was recently in India to attend a science congress, said that an estimated 18,000 students have been affected by the closure of most of the nine universities in Sri Lanka. The government approached several countries to ask if they would accept at least 1,000 students but, so far the only offer is from India which has agreed to take 500 of them. Ponnemperuma that the offer by India will strengthen Indo-Sri Lankan ties and that "what the countries failed to achieve at the political level, might be achieved at the educational level".

The project will cost India about $\$ 3$ million a year and will be administered by the University Grants Commission and the Indian Council of Cultural Relations. According to the chairman of the grants commission, Professor Yash Pal, the External Affairs Ministry will mobilize the needed financial resources.

K. S. Jayaraman

of Biology said that Romania needs a "new model" for supervising research. "But we don't know what it is", he said. "We are still waiting for instructions from someone. After 45 years of following the orders of authority, it is hard to change ourselves within one month." People are aware that Romania has more than a little catching up to do. Botnariuc of the academy said that "Romania's main problem is not the economy, which can be rebuilt with some effort. The biggest damage [of the dictatorship] was to people's psyches and their intellects. All the important things in their lives were distorted - morals, ethics, their mentality. These are the hardest to change because they go so deep."

The period of uncertainty will probably last well beyond the elections scheduled for May. Many people see the need for more shaking out of Ceausescu sympathizers before the scientific institutes, or the society as a whole, can go on in peace. As Hulea put it, "people who were quiet here for a long time are suddenly revolutionaries. It's very strange." A story going around Bucharest has it that Diogenes came to Romania this month looking for someone who did not participate in the revolution. He has yet to find one.

Steven Dickman 